\title{
Rancang Bangun Tomografi Kapasitansi Listrik dengan Sensor Tersegmentasi dan Berperisai untuk Deteksi Benda Dalam Pipa
}

\author{
Ardian Wardhana, Muhammad Rivai, Fajar Budiman, dan Saikhul Imam \\ Jurusan Teknik Elektro, Fakultas Teknologi Industri, Institut Teknologi Sepuluh Nopember (ITS) \\ Jl. Arief Rahman Hakim, Surabaya 60111 Indonesia \\ e-mail: ardian.wardhana@gmail.com,muhammad_rivai@ee.its.ac.id,fajarbudiman@ee.its.ac.id
}

\begin{abstract}
Abstrak-Tomografi merupakan teknik pengamatan struktur penampang benda tanpa melakukan tindakan yang bersifat merusak atau mengubah benda yang dibutuhkan dalam penerapan industri, kesehatan maupun keamanan. Pengamatan dilakukan dengan memanfaatkan interaksi bahan dalam benda terhadap sinyal eksitasi eksternal. Hasil pengukuran digunakan untuk merekonstruksi struktur penampang internal benda. Pada penelitian ini dilakukan perancangan sistem tomografi kapasitansi listrik dengan menggunakan sensor tersegmentasi dan berperisai. Tomografi kapasitansi listrik memanfaatkan informasi perbedaan nilai kapasitansi pada beberapa garis potong yang disebabkan oleh persebaran permittivitas bahan untuk merekonstruksi struktur bagian dalam benda. Konfigurasi sensor diatur dengan menggunakan multiplekser analog yang terdiri dari array switch CMOS HEF4066B. Pengukuran kapasitansi sensor dilakukan dengan metode pengukuran muatan. Sinyal hasil pengukuran dikondisikan dengan menggunakan filter high-pass, penguat, penyearah presisi dan perata-rata, yang kemudian didigitalkan menggunakan ADC pada mikrokontroller ATmega8A. Pengolahan data dilakukan dengan menggunakan komputer. Rekonstruksi citra dilakukan dengan algoritma proyeksi balik linier. Berdasarkan hasil pengujian, sistem tomografi kapasitansi listrik dapat mendeteksi letak dan membedakan bahan benda uji. Penggunaan sensor tersegmentasi mampu meningkatkan sensitivitas pengukuran kapasitansi sebesar 2,76 kali lipat dari penggunaan sensor tunggal dengan nilai sensitivitas $0,515 \mathrm{~V} / \mathrm{pF}$. Penggunaan sensor berperisai mampu mengurangi efek gangguan lingkungan terhadap pengukuran sensor. Hasil dari penelitian ini dapat diimplementasikan sebagai alat pemonitor isi pipa pada industri dengan kebutuhan regulasi yang rendah.
\end{abstract}

Kata Kunci- proyeksi balik linier; sensor tersegmentasi; tomografi kapasitansi listrik

\section{PENDAHULUAN}

$\mathrm{T}$ OMOGRAFI merupakan teknik pengamatan struktur penampang benda tanpa melakukan tindakan yang bersifat merusak atau mengubah benda. Kemampuan melakukan pengamatan penampang benda tanpa merusak atau mengubah fisik benda dibutuhkan dalam penerapan industri, kesehatan maupun keamanan.

Pengamatan dapat dilakukan dengan memanfaatkan interaksi bahan dalam benda terhadap sinyal eksitasi eksternal. Dengan mengamati perubahan sinyal yang diakibatkan oleh benda, komposisi dan struktur benda dapat direkonstruksi. Terdapat beberapa metode tomografi berdasarkan sinyal eksitasi yang digunakan, antara lain tomografi optik menggunakan sinar tampak, tomografi elektromagnetik menggunakan gelombang radio, tomografi radiologi menggunakan sinar- $\mathrm{X}$ atau sinar gamma, dan tomografi listrik menggunakan deteksi kapasitansi atau induktansi.

Tomografi kapasitif memanfaatkan informasi distribusi kapasitansi yang disebabkan oleh perbedaan nilai permittivitas bahan untuk merekonstruksi struktur bagian dalam benda. Benda dipindai dengan cara mengukur nilai kapasitansi yang ditimbulkan oleh benda pada sepasang sensor kapasitor pelat sejajar. Pengukuran dilakukan berkali-kali pada garis potong yang berbeda-beda sehingga diperoleh data kapasitansi yang meliputi seluruh bagian penampang benda. Hasil pengukuran kapasitansi diolah dengan algoritma rekonstruksi citra sehingga didapatkan representasi penampang benda dalam bentuk citra dua dimensi.

Untuk mendapatkan hasil pemindaian yang memiliki tingkat resolusi dan akurasi tinggi, diperlukan konstruksi sensor dengan komponen parasitik rendah, pengukuran kapasitansi yang akurat dan algoritma rekonstruksi citra yang baik. Pengembangan-pengembangan yang telah dilakukan antara lain adalah penggunaan sensor tersegmentasi, sensor berperisai, pengukuran dan sensor differensial, serta algoritma rekonstruksi iteratif.

Karena menggunakan pengukuran kapasitansi, tomografi elektronik kapasitif memiliki kelebihan berupa penggunaan sinyal eksitasi yang tidak mengakibatkan bahaya radiasi, dapat mengamati bahan yang tidak tembus radiasi (opaque), serta implementasi yang relatif sederhana [1].

Aplikasi dari tomografi kapasitansi listrik antara lain adalah untuk pengamatan isi dan bahan yang mengalir pada pipa, terutama pada bahan yang mungkin terjadi kontaminasi dan segregasi.

\section{TEORI PENUNJANG}

\section{A. Tomografi Kapasitansi Listrik}

Tomografi merupakan metode pencitraan penampang (potongan) benda dengan melakukan rekonstruksi nondestruktif dan non-invasif. Tomografi Kapasitansi Listrik menggunakan informasi distribusi spasial kapasitansi antara dua pasang keping konduktor untuk merekonstruksi komposisi 


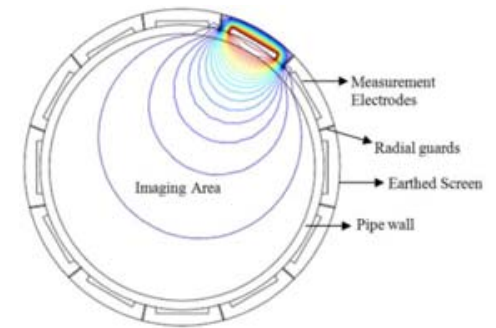

Gambar 1. Penampang melintang sensor tomografi kapasitansi listrik dengan salah satu elektroda dieksitasi tegangan [2]

internal benda [3]. Sistem perangkat keras tomografi kapasitif terdiri dari sensor kapasitif, multiplekser analog, pengukur kapasitansi dan konverter analog ke digital [4].

Komponen sensor yang digunakan berupa pelat-pelat konduktor yang disusun melingkar mengelilingi benda uji. Dengan melakukan pengukuran terhadap berbagai kombinasi pelat konduktor, dapat didapatkan informasi nilai kapasitansi untuk potongan-potongan tertentu.

Berdasarkan persamaan kapasitor, nilai kapasitansi antara dua buah pelat konduktor ditentukan oleh luas, jarak dan permittivitas benda. Untuk suatu pasangan elektroda $(x, y)$ yang membentangi bidang $\Gamma$, kapasitansi yang terukur mengikuti persamaan 1 .

$$
C=-\frac{1}{V} \iint_{\Gamma} \varepsilon_{(x, y)} \nabla v_{(x, y)} d \Gamma
$$

Gambar 1 menunjukkan penampang melintang persebaran medan listrik pada sensor tomografi ketika salah satu elektroda dieksitasi tegangan listrik $(V)$. Perbedaan nilai permittivitas pada imaging area $\left(\varepsilon_{(x, y)}\right)$ yang disebabkan oleh perbedaan komposisi beda menyebabkan perubahan pola dan intensitas medan listrik $\left(v_{(x, y)}\right)$ pada benda. Hal tersebut menyebabkan perbedaan nilai kapasitansi yang terukur pada pasangan-pasangan pelat konduktor [4].

Desain sensor merupakan kompromi antara sensitivitas dan resolusi. Untuk mendapatkan sensitivitas yang baik, pelat elektroda harus memiliki luas permukaan sebesar mungkin sehingga didapatkan pengukuran kapasitansi dengan nilai sinyal yang lebih besar. Sedangkan untuk mendapatkan resolusi yang baik, jumlah pelat elektroda harus sebanyak mungkin sehingga dapat diperoleh pengukuran kapasitansi yang lebih rapat.

\section{B. Sensor Tersegmentasi}

Resolusi pada sistem tomografi kapasitansi listrik merupakan hasil kompromi antara jumlah sensor dan luas permukaan sensor. Untuk system dengan diameter yang sama, penambahan

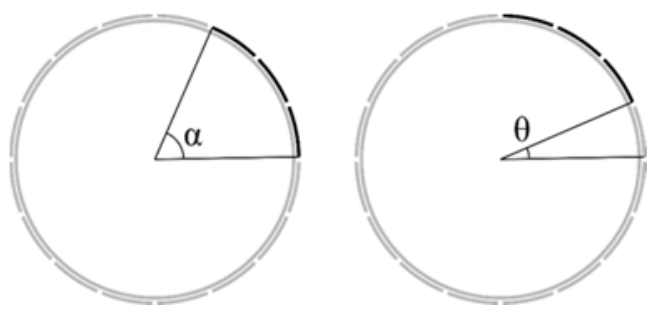

Gambar 2. Penggunaan sensor tersegmentasi memungkinkan resolusi sudut $\alpha$ untuk luasan sensor $\theta$.

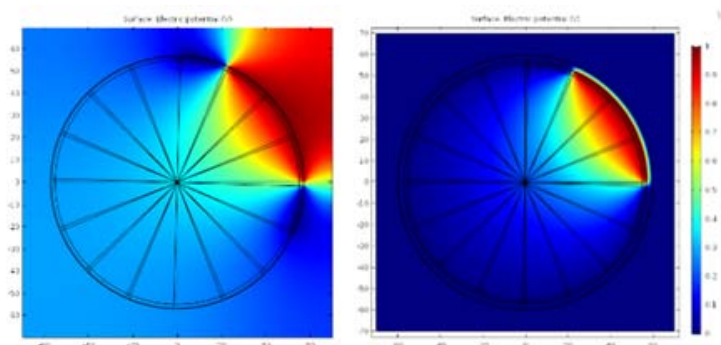

Gambar 3. Perbandingan sebaran medan listrik pada sensor tanpa perisai (kiri) dan sensor berperisai (kanan).

jumlah sensor untuk meningkatkan resolusi pengukuran kapasitansi akan berakibat pada berkurangnya luas permukaan tiap pelat sensor yang dapat digunakan untuk mengukur kapasitansi.

Berkurangnya luas permukaan pelat sensor berakibat pada berkurangnya nilai kapasitansi yang timbul antara dua sensor saat dilakukan pengukuran. Nilai kapasitansi yang lebih kecil membutuhkan rangkaian pengkondisi dan akuisisi data yang lebih sensitif dan memiliki tingkat derau yang rendah sehingga sinyal tidak tenggelam oleh gangguan derau. [5]

Penggunaan sensor tersegmentasi dengan konstruksi dan konfigurasi seperti pada Gambar 2 merupakan salah satu metode untuk mendapatkan jumlah pengukuran yang besar tanpa mengorbankan luas permukaan sensor $(\alpha)$. Pada sensor tersegmentasi, sensor dibagi menjadi pelat-pelat elektroda kecil yang digabungkan menjadi satu saat dilakukan pengukuran. Dengan mengubah konfigurasi pelat-pelat yang digabungkan, dapat dilakukan pengukuran kapasitansi dengan selisih sudut $(\theta)$ yang lebih kecil dari penggunaan sensor tunggal [6].

\section{Sensor Berperisai}

Nilai kapasitansi antara dua pelat elektroda bergantung pada persebaran nilai permittivitas dielektrik dan persebaran medan listrik pada bahan dielektrik. Tomografi kapasitif menggunakan informasi persebaran permittivitas dielektrik sehingga untuk mendapatkan pengukuran yang akurat, gangguan terhadap persebaran medan listrik harus dibatasi serendah mungkin [7].

Salah satu metode penguangan gangguan lingkungan terhadap persebaran medan listrik sensor adalah dengan menggunakan perisai yang dihubungkan dengan referensi (ground) sinyal. Perisai berfungsi untuk membatasi medan listrik yang dibangkitkan oleh sensor sehingga hanya terfokus pada sisi dalam sensor seperti pada Gambar 3.

\section{Algoritma Proyeksi Balik Linier}

Terdapat beberapa algoritma rekonstruksi citra dari data hasil pengukuran kapasitansi. Algoritma yang dipilih pada umumnya merupakan kompromi antara kompleksitas perhitungan dan keakuratan hasil rekonstruksi yang diinginkan [8].

Distribusi medan listrik yang bersifat nonlinier dan sedikitnya jumlah pengukuran dibandingkan dengan jumlah piksel yang harus direkonstruksi merupakan kendala besar dalam proses rekonstruksi citra. Untuk memecahkan masalah, pada umumya digunakan dua pendekatan yaitu metode 
proyeksi balik linier dan metode optmasi.

Pada metode proyeksi balik linier (linear back projection), hasil pengukuran kapasitansi diproyeksikan pada matriks sensor sehingga didapatkan citra dua dimensi dari persebaran permittivitas bahan yang diobservasi. Metode proyeksi balik linier melakukan perhitungan distribusi permittivitas dengan melakukan pemetaan linier hasil pengukuran kapasitansi dan matrik sensitivitas.

Proses rekonstruksi citra tomografi kapasitansi meliputi dua tahap komputasi, yaitu forward problem dan inverse problem. Forward problem menghitung distribusi potensial yang disebabkan oleh adanya distribusi permittivitas, sedangkan inverse problem menghitung distribusi permittivitas berdasarkan hasil pengukuran kapasitansi. Hasil dari penyelesaian inverse problem pada umumnya disajikan dalam bentuk citra dua dimensi, sehingga proses tersebut disebut sebagai proses rekonstruksi citra [4].

Pada forward problem, nilai kapasitansi yang terukur pada pasangan-pasangan elektroda sensor dapat diinyatakan sebagai fungsi terhadap distribusi permittivitas dan peta sensitivitas [9].

$$
C_{i j}=\iint_{\Gamma} \varepsilon(x, y) S_{i j}(x, y) d x d y
$$

$C_{i j}$ merupakan nilai kapasitansi antara pasangan elektroda $i$ dan $j, \varepsilon(x, y)$ merupakan nilai permittivitas bahan pada koordinat $(x, y), S_{i j}(x, y)$ merupakan nilai sensitivitas koordinat $(x, y)$ untuk pasangan elektroda $i-j$, dan $\Gamma$ merupakan permukaan elektroda.

Persamaan dapat dilinearisasi dan dinyatakan dalam bentuk diskrit sebagai.

$$
C=G S
$$

$C$ merupakan matriks kapasitansi dengan dimensi sebanyak jumlah pengukuran kombinasi pasangan-pasangan elektroda, $G$ merupakan matriks distribusi permittivitas bahan dan $S$ merupakan peta sensitivitas.

Inverse problem dari persamaan tersebut dapat direkonstruksi dengan persamaan dasar invers matriks.

$$
G=C S^{-1}
$$

Persamaan tidak dapat diselesaikan secara analitk karena jumlah pengukuran yang dilakukan untuk $\mathrm{C}$ jauh lebih sedikit dari jumlah piksel pada G. Perhitungan distribusi permittivitas dapat dilakukan dengan melakukan pendekatan menggunakan transpos matriks peta sensitivitas.

$$
\widehat{G}=C S^{T}
$$

Metode proyeksi balik linier menggunakan persamaan penjumlahan linier tiap piksel yang dipengaruhi oleh hasil pengukuran dengan pembobotan dari peta sensitivitas. Nilai permittivitas pada piksel $x, y(G(x, y))$ ditentukan berdasarkan persamaan $6[10]$.

$$
G(x, y)=\frac{\sum_{i=1}^{N-1} \sum_{j=i+1}^{N} S_{i j}(x, y) C_{i j}}{\sum_{j=i+1}^{N} S_{i j}(x, y)}
$$

$S_{i, j}(x, y)$ merupakan nilai sensitivitas pada piksel $x, y$ untuk pasangan elektroda $i$ dan $j . C_{i, j}$ merupakan nilai hasil pengukuran kapasitansi pada pasangan elektroda $i$ dan $j$. $m$ dan

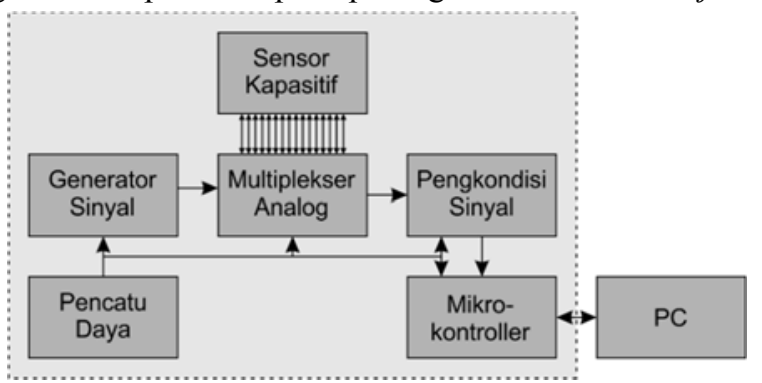

Gambar 4. Diagram blok perangkat keras tomografi kapasitansi

$n$ merupakan jumlah elektroda yang digunakan sebagai sumber eksitasi dan pengukuran kapasitansi (sense) pada proses pemindaian [11].

\section{PERANCANGAN SISTEM}

\section{A. Diagram Blok Sistem}

Sistem tomografi kapasitansi listrik secara umum terdiri dari perangkat keras dan perangkat lunak. Perangkat keras terdiri dari blok sensor kapasitif, multiplekser analog, generator sinyal, pengkondisi sinyal, mikrokontroller, pencatu daya dan pengolah data menggunakan komputer personal. Konfigurasi komponen ditunjukkan pada Gambar 4.

(3) Perangkat lunak terdiri dari firmware pada mikrokontroller yang digunakan sebagai pengendali sensor dan akuisisi data, serta perangkat lunak rekonstruksi citra pada komputer.

\section{B. Sensor Kapasitif}

Sensor kapasitif untuk sistem tomografi menggunakan 16 buah pelat tembaga dengan ketebalan $0.25 \mathrm{~mm}$ berukuran $2 \mathrm{~cm}$ $\mathrm{x} 12 \mathrm{~cm}$ yang disusun melingkar pada pipa PVC berdiameter $4,5)$ inci $(11,43 \mathrm{~cm})$. Tiap pelat sensor dihubungkan ke rangkaian multiplekser analog dengan menggunakan kabel koaksial.

Sisi luar sensor dilapisi dengan perisai berupa pelat tembaga yang dihubungkan ke potensial ground sistem. Lapisan perisai dipisahkan dari pelat-pelat sensor denagan menggunakan perekat polypropilen setebal $1 \mathrm{~mm}$. Hasil konstruksi diflunjukkan pada Gambar 5.

\section{Multiplekser Analog}

Rangkaian scanning elektroda dirangkai dari komponen multiplekser analog. Untuk mendapatkan respons system yang cepat dan handal, digunakan switch CMOS HEF4066B. Switch dioperasikan pada catu daya 15 volt $\left(\mathrm{V}_{\mathrm{SS}}-7,5\right.$ volt dan $\mathrm{V}_{\mathrm{DD}}+7,5$ volt) utuk memaksimalkan amplitudo sinyal eksitasi yang dapat 


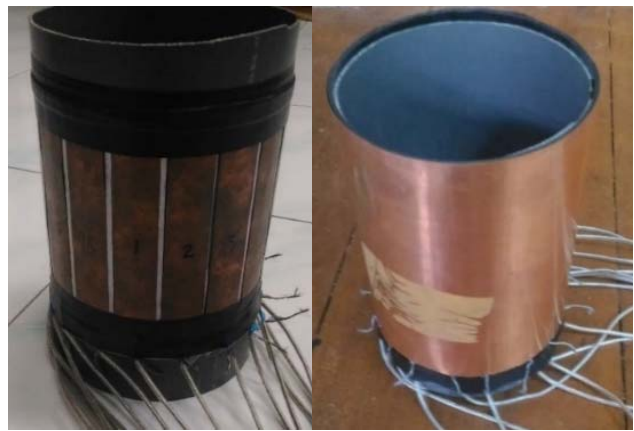

Gambar 5. Implementasi sensor kapasitif menunjukkan konstruksi segmentasi (kiri) dan perisai (kanan).

melewati switch. Dengan catu daya 15 volt, switch dapat melewatkan sinyal dengan amplitudo $14 \mathrm{Vpp}$.

Setiap elektroda dilengkapi dengan 6 buah switch CMOS dengan pembagian 3 switch untuk masing-masing fungsi elektroda. Switch disusun dalam topologi $\mathrm{T}$ untuk mengurangi kebocoran muatan saat switch dalam keadaan non aktif [12].

Komparator LM393D digunakan untuk mengubah sinyal logika TTL 5 volt dari mikrokontroller menjadi logika CMOS dengan ayunan tegangan $-7,5$ volt untuk logika 0 dan $+7,5$ volt untuk logika 1.

\section{Generator Sinyal}

Generator sinyal berfungsi untuk membangkitkan sinyal eksitasi elektroda pada sensor kapasitif. Generator sinyal diimplementasikan dengan menggunakan IC ICL8030 untuk membangkitkan gelombang sinusoidal dengan frekuensi $200 \mathrm{KHz}$.

Digunakan resistor sebesar $11 \mathrm{KOhm}$ dan kapasitor sebesar $150 \mathrm{pF}$ untuk mendapatkan frekuensi osilasi sebesar $200 \mathrm{KHz}$. Resistor R1 dan R2 bernilai sama untuk mendapatkan gelombang sinus yang simetris pada sisi naik dan sisi turun. R3 dan R9 digunakan untuk mengubah bentuk gelombang sehingga simetris pada sisi positif dan sisi negatif.

\section{E. Pengkondisi Sinyal}

Pengkondisi sinyal terdiri dari blok angkaian penguat muatan yang berfungsi untuk menkonversi sinyal muatan dari sensor menjadi sinyal tegangan, filter low-pass untuk memblok sinyal DC dan interferensi frekuensi jala-jala listrik, penguat noninverting untuk menguatkan sinyal, penyearah presisi dan filter low-pass untuk mengkonversi sinyal arus bolak-balik sinusoidal menjadi sinyal arus searah, dan penguat selisih untuk mengatur nilai offset sinyal keluaran. Konfigurasi rangkaian dan alur aliran sinyal pada pengkondisi sinyal ditunjukkan pada diagram blok Gambar 6 .

Penguat muatan digunakan untuk mengkonversi sinyal muatan dari sensor kapasitif menjadi sinyal tegangan. Karakteristik sensor kapasitif dan multiplekser analog memiliki rentang kapasitansi total sensor dan parasitik sebesar $2 \mathrm{pF}$ hingga $10 \mathrm{pF}$ sehingga untuk mendapatkan penguatan sebesar $1(0 \mathrm{~dB})$ pada kapasitansi maksimum, digunakan kapasitor $10 \mathrm{pF}$ sebagai komponen umpanbalik negatif. Resistor umpanbalik $\mathrm{R}_{1}$ sebesar $10 \mathrm{M} \Omega$ digunakan untuk mencegah rangkaian beroperasi pada mode loop terbuka.

Filter high pass digunakan untuk memblok komponen DC pada sinyal sensor yang disebabkan oleh arus bocor pada multiplekser serta komponen frekuensi rendah yang disebabkan oleh jala-jala listrik. Topologi filter yang digunakan merupakan filter Sallen-Key dengan frekuensi cutoff $100 \mathrm{KHz}$ dan respons Bessel $(\mathrm{Q}=0,58)$.

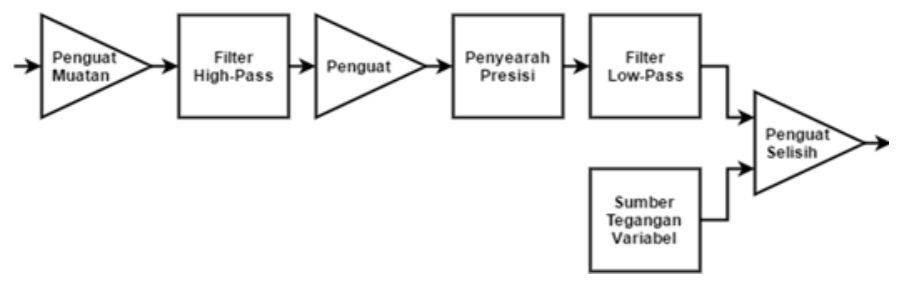

Gambar 6. Diagram blok rangkaian pengkondisi sinyal.

Penguat noninverting digunakan utuk menguatkan sinyal tegangan hasil konversi penguat muatan lebih lanjut. Penguatan dilakukan dalam dua tingkat untuk memperkecil kebutuhan gain-bandwidth product (GBW) pada penguat operasional.

Penyearah presisi digunakan untuk menyearahkan sinyal arus bolak-balik dari keluaran sensor menjadi sinyal arus searah

sehingga dapat dirata-rata dan dikonversi oleh ADC mikrokontroller yang memerlukan sinyal monopolar positif.

Filter lowpass digunakan untuk merata-rata gelombang sinyal sensor yang telah disearahkan sehingga dapat diakuisisi oleh ADC. Filter menggunakan topologi Sallen-Key dengan frekuensi cutoff sebesar $10 \mathrm{KHz}$ dengan respons Bessel.

Pengurang offset digunakan untuk mengeliminasi offset sinyal yang disebabkan oleh kapasitansi parasitic pada sensor dan multiplekser analog, sedangkan penguat digunakan untuk menguatkan sinyal sehingga sinyal keluaran memiliki tegangan maksimum sebesar tegangan maksimum ADC. Hal tersebut bertujuan untuk memaksimalkan resolusi ADC.

\section{F. Mikrokontroller}

Mikrokontroller digunakan untuk mengatur konfigurasi multiplekser analog, mengakuisisi sinyal dan mengkonversi sinyal ke digital, serta mengirimkan sinyal ke komputer melalui protokol RS232.

Pengaturan konfigurasi switch diatur menggunakan data serial melalui dua pin GPIO mikrokontroller sebagai data dan clock sinkronisasi. Akuisisi sinyal sensor dilakukan dengan menggunakan peripheral ADC internal pada mikrokontroller AVR. Konversi dilakukan $5 \mathrm{~ms}$ setelah multiplekser analog selesai dikonfigurasi untuk meyakinkan bahwa tegangan keluaran rangkaian pengkondisi sinyal telah stabil pada nilai sinyal yang baru. Tiap sensor dilakukan konversi sebanyak empat kali dan dirata-rata untuk mengurangi efek derau pada pengukuran.Komunikasi RS232 menggunakan peripheral USART pada mikrokontroller yang ditranslasikan menjadi level tegangan RS232 oleh IC MAX232.

\section{G. Rekonstruksi Citra}

Rekonstruksi citra tomografi diimplementasikan dengan menggunakan Visual Basic yang dikembangkan menggunakan IDE Microsoft Visual Studio. Perangkat lunak berfungsi untuk mengolah data hasil pengukuran menjadi data persebaran 
permittivitas dan menampilkan data pernmittivitas dalam bentu citra. Perangkat lunak terdiri dari empat bagian utama, yaitu bagian pengatur komunikasi serial, bagian pemuat peta sensitivitas, bagian rekonstruksi citra dan bagian penampil data.

Program rekonstruksi citra melakukan proses pengolahan data setiap terjadi penerimaan data melalui komunikasi serial. Setiap terjadi penerimaan data, subprogram melakukan parsing data dari format teks serial menjadi variabel-variabel integer pada array masukan pengukuran dengan dimensi $72 \times 1$. Data tiap pengukuran kemudian dinormalisasi dengan membagi nilai variabel dengan 1024 (nilai maksimum data pengukuran).

Nilai permittivitas pada tiap-tiap piksel kemudian dihitung dengan menjumlahkan hasil kali nilai sensitivitas piksel tersebut dengan nilai hasil pengukuran pada pasangan elektroda yang bersesuaian sesuai dengan Persamaan 7. Nilai dinormalisasi dengan jumlah nilai sensitivitas pada piksel tersebut pada seluruh pasangan elektroda.

$$
G(x, y)=\frac{\sum_{n=1}^{72} S_{n}(x, y) C_{n}}{\sum_{n=1}^{72} S_{n}(x, y)}
$$

Nilai permittivitas pada tiap piksel ditampilkan sebagai gradien warna (hue) pada ruang warna HSV. Rentang gradien warna yang digunakan adalah rentang nilai $\mathrm{H}=90$ (cyan) untuk nilai data 0 , hingga $\mathrm{H}=0$ (merah) untuk nilai data 1 .

\section{PENGUJIAN DAN ANALISIS DATA}

Pengujian alat dilakukan dengan cara menguji respons masing masing blok penyusun sistem serta menguji respons sistem secara keseluruhan.

\section{A. Pengujian Sensor}

Pengujian respons sensor tersegmentasi dilakukan dilakukan dengan cara mengukur nilai kapasitansi pasanganpasangan elektroda sensor pada frekuensi operasi $200 \mathrm{kHz}$ dengan benda uji udara $\left(\varepsilon_{\mathrm{r}}=1\right)$ dan air $\left(\varepsilon_{\mathrm{r}}=80\right)$ pada suhu ruang $27^{\circ} \mathrm{C}$. Pengukuran kapasitansi dilakukan dengan mengukur nilai tegangan keluaran penguat muatan yang dikalibrasi terhadap kapasitansi masukan dengan menggunakan LCR-meter.

Dari hasil pengukuran pada Tabel 1 dapat diketahui bahwa penggunaan sensor tersegmentasi dapat meningkatkan nilai kapasitansi yang terukur pada tiap posisi pengukuran. Sensor elektroda tunggal memiliki sensitivitas terhadap perbedaan permittivitas sebesar $0,0143 \mathrm{pF} / \varepsilon_{\mathrm{r}}$ untuk elektroda berdekatan dan $0,0059 \mathrm{pF} / \varepsilon_{\mathrm{r}}$ untuk elektroda berlawanan. Sensor elektroda tersegmentasi memiliki sensitivitas terhadap perbedaan permittivitas sebesar $0,0384 \mathrm{pF} / \varepsilon_{\mathrm{r}}$ untuk elektroda berdekatan dan $0,0178 \mathrm{pF} / \varepsilon_{\mathrm{r}}$ untuk elektroda berlawanan. Penggunaan elektroda tersegmentasi sebanyak tiga buah dapat meningkatkan sensitivitas sebesar 2,76 kali dari penggunaan elektroda tunggal.

Pengujian sensor berperisai dilakukan untuk mengukur sensitivitas sensor berperisai terhadap gangguan luar dan membandingkan respons yang didapat dengan respons sensor yang tidak berperisai. Pengujian dilakukan dengan mengukur amplitudo sinyal yang dideteksi elektroda sensor ketika sensor diberi gangguan berupa air dalam botol pada bagian luar sensor.

Tabel 1. Perbandingan respons sensor tunggal dengan sensor tersegmentasi

\begin{tabular}{ccc}
\hline \hline \multicolumn{2}{c}{ Sensitivitas $\left(\mathrm{pF} / \varepsilon_{\mathrm{r}}\right)$} & $\begin{array}{c}\text { Perbandingan } \\
\left(\mathrm{S}_{\mathrm{seg}} / \mathrm{S}_{\mathrm{tgl}}\right)\end{array}$ \\
\cline { 1 - 2 } Tunggal & Tesegmentasi & 2,626 \\
0,0149 & 0,0391 & 2,736 \\
0,0098 & 0,0267 & 2,838 \\
0,0072 & 0,0204 & 2,907 \\
0,0061 & 0,0178 & 2,803 \\
0,0059 & 0,0166 & 2,720 \\
0,0062 & 0,0169 & 2,726 \\
0,0075 & 0,0204 & 2,748 \\
0,0087 & 0,0239 & 2,741 \\
0,0137 & 0,0377 & 2,760 \\
\hline
\end{tabular}

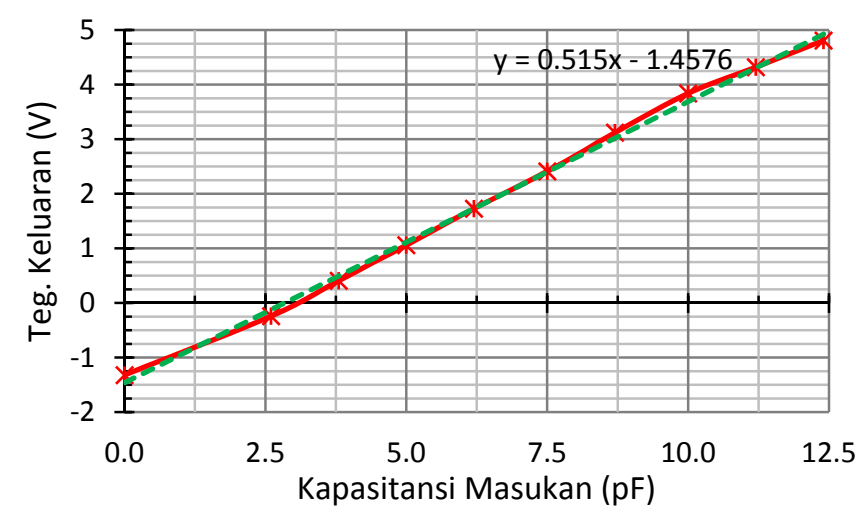

Gambar 7. Grafik respons tegangan keluaran rangkaian pengkondisi sinyal terhadap nilai kapasitansi masukan

Hasil pengujian menunjukkan bahwa penggunaan perisai dapat meniadakan efek gangguan benda luar pada bidang radial sensor. Penggunaan perisai pada sensor menyebabkan pelemahan sinyal yang diterima oleh sistem akuisisi data.

\section{B. Pengujian Pengkondisi Sinyal}

Pengujian rangkaian pengkondisi sinyal dilakukan dengan menguji respons rangkaian secara keseluruhan untuk mengetahui karakteristik dan linearitas rangkaian terhadap kapasitansi masukan. Pengujian respons keseluruhan pengkondisi sinyal dilakukan dengan mengukur nilai tegangan keluaran sistem terhadap nilai kapasitansi masukan yang telah dikalibrasi menggunakan LCR-meter. Kapasitansi masukan dieksitasi dengan sinyal sinusoidal frekuensi $200 \mathrm{kHz}$ dan amplitudo 14 Volt.

Dari grafik data hasil pengujian pada Gambar 7, diketahui rangkaian pengkondisi sinyal memiliki sensitivitas sebesar $0,515 \mathrm{~V} / \mathrm{pF}$ dan offset sebesar $1,458 \mathrm{~V}$. Offset digunakan untuk mengkompensasi komponen parasitik rangkaian.

\section{Pengujian Rekonstruksi Citra}

Pengujian dilakukan dengan meletakkan benda pada sensor dan mengamati citra hasil rekontruksi. Benda uji berupa botol berbentuk tabung dan prismatik yang diisi dengan air. 

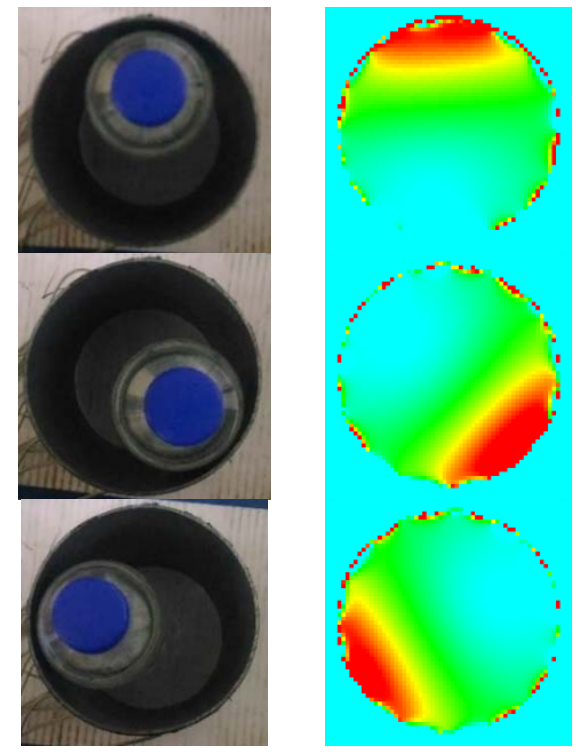

Gambar 8. Perbandingan posisi benda uji dan citra hasil rekonstruksi sistem tomografi kapasitansi listrik
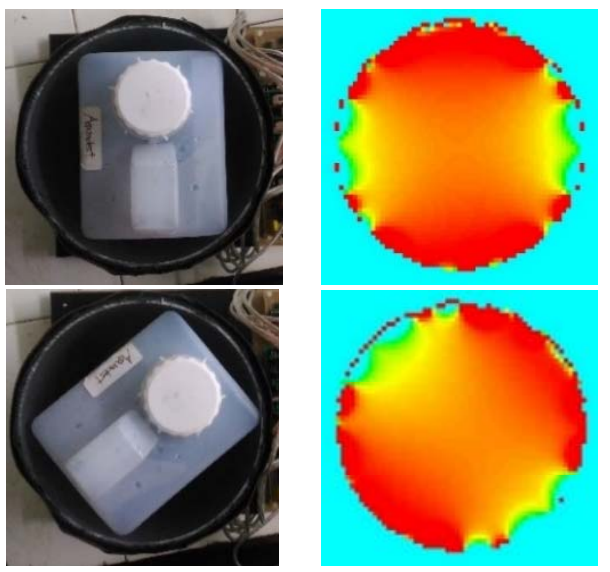

Gambar 9. Perbandingan bentuk dan posisi benda uji dan citra hasil rekonstruksi

Data hasil pengujian rekonstruksi citra untuk objek botol berisi air yang diletakkan di tepi sensor ditunjukkan pada Gambar 8. Hasil menunjukkan bahwa citra rekonstruksi dapat menunjukkan posisi objek dengan tepat namun kurang baik dalam rekonstruksi bentuk objek.

Pengujian respons sistem terhadap botol air berbentuk prismatik ditunjukkan pada Gambar 9. Hasil menunjukkan bahwa rekonstruksi objek mampu merekonstruksi bentuk benda secara umum namun belum dapat membedakan bentuk bendasecara akurat dan detail.

Pengujian selektivitas dilakukan untuk menguji kemampuan sistem tomografi dalam membedakan berbagai macam bahan. Pengujian dilakukan dengan mengisi sensor dengan bahan uji hingga penuh. Bahan uji dikemas dalam kantong plastik agar tidak mengkontaminasi sensor. Bahan uji yang digunakan merupakan air, minyak goreng, biosolar, methyl alkohol $80 \%$, dan larutan ammonium hidroksida (ammonia) 30\%. Nilai pengukuran didapatkan dengan merata-rata nilai hasil rekonstruksi pada $50 \%$ bagian tengah sensor. Pengambilan data pengujian pada bagian tengah sensor ditujukan agar pegukuran tidak terpengaruh nilai pengukurn tepi yang sangat tinggi. Hasil pengujian ditunjukkan pada Tabel 2.

Hasil pengujian pada Tabel 2 menunjukkan bahwa sistem tomografi dapat membedakan bahan benda uji berdasarkan perbedaan permittivitas bahan. Permittivitas air yang relatif tinggi menyebabkan sistem mengalami saturasi. Bahan-bahan yang memiliki nilai permittivitas yang saling berdekatan sulit dibedakan secara visual. Benda uji berbahan minyak goreng, ammonium hidroksida dan methyl alkohol menghasilkan rekonstruksi citra yang mirip secara visual, namun dapat dibedakan dengan menganalisis nilai perhitungan tiap piksel.

Tabel 2. Pengujian respons bahan homogen

\begin{tabular}{cc}
\hline \hline Bahan Uji & Nilai Rekonstruksi \\
\hline Air & 1 \\
Minyak Goreng & 0,233 \\
Biosolar & 0,147 \\
Methyl Alkohol 80\% & 0,406 \\
Ammonium Hidroksida 30\% & 0,297 \\
\hline \hline
\end{tabular}

\section{KESIMPULAN}

Dari perancangan, realisasi, dan pengujian alat pada penelitian ini dapat disimpulkan bahwa penggunaan elektroda tersegmentasi mampu meningkatkan sensitivitas sensor terhadap perubahan nilai permittivitas sebesar 2,76 kali lipat lebih besar jika dibandingkan dengan sensor elektroda tunggal. Penggunaan sensor berperisai mampu mengurangi efek gangguan eksternal terhadap hasil pengukuran sensor. Rangkaian pengkondisi sinyal memiliki sensitivitas sebesar $0,515 \mathrm{~V} / \mathrm{pF}$. Sistem akuisisi data secara keseluruhan memiliki sensitivitas sebesar $0,96 \mathrm{LSB} / \varepsilon_{\mathrm{r}}$ pada sensor yang berdekatan dan $0,75 \mathrm{LSB} / \varepsilon_{\mathrm{r}}$ pada sensor yang berseberangan.

Sistem tomografi yang dihasilkan dapat mendeteksi posisi benda secara akurat namun belum dapat membedakan betuk benda secara akurat. Sistem memiliki sensitivitas tertinggi ketika benda berada pada bagian tepi sensor. Sistem dapat mendiferensiasikan bahan benda berdasarkan perbedaan nilai permittivitas bahan. Sistem tomografi kapasitansi listrik dapat digunakan untuk mendeteksi posisi benda dalam pipa tanpa melakukan pengukuran yang invasif maupun destruktif.

\section{DAFTAR PUSTAKA}

[1] M. Neumayer, G. Steiner and D. Watzenig, "Electrical Capacitance Tomography: Current Sensors/Algorithms and future Advances," in Instrumentation and Measurement Technology Conference (I2MTC), Mei 2012.

[2] A. Shafquet, I. Ismail and A. Jaafar, "Modeling and Simulation of MultiPlane Electrical Capacitance Tomography Sensor for Flow Imaging by Using Finite Element Analysis," in 5th International Conference on Intelligent and Advanced Systems (ICIAS), Juni 2014.

[3] H. Herdian, "Hardware Implementation of Linear Back-Projection Algorithm for Capacitance Tomography," ICICI-BME, vol. 4, pp. 124129, November 2015.

[4] F. Wang, Q. Marashdeh, L. S. Fan and Warsito, "Electrical Capacitance Volume Tomography: Design and Application," Sensors, vol. 10, pp. 1890-1917, 2010.

[5] A. M. Olmos, M. Carvajal, D. Morales, A. García and A. Palma, "Development of an Electrical Capacitance Tomography system using four rotating electrodes," Sensors and Actuators A, vol. 148, pp. 366-375, 
2008.

[6] S. M. Din, N. A. M. Razali, A. Azmi, C. P. Song, R. A. Rahim and L. P. Ling, "Comparison of Single and Segmented Excitation of Electrical Capacitance Tomography," in 10th Asian Control Conference, Juni 2015.

[7] K. J. Alme and S. Mylvaganam, "Electrical Capacitance TomographySensor Models, Design, Simulations, and Experimental Verification," IEEE SENSORS JOURNAL, vol. 6, no. 5, pp. 1256-1266, Oktober 2006.

[8] J. Nombo1, A. Mwambela and M. Kisangiri, "A Review of Image Reconstruction Methods in Electrical Capacitance Tomography," Journal of Mathematical and Computational Science, vol. 6, no. 1, pp. 39-57, 2016.

[9] W. Q. Yang and L. H. Peng, "Image reconstruction algorithms for electrical capacitance tomography," Measurement Science and Technology, no. 14, pp. R1-R13, 2003.

[10] F. Dickin and M. Wang, "Electrical resistance tomography for process applications," Measurement Science and Technology, vol. 7, no. 3, pp. 247-260, 1996.

[11] Pusat Pengembangan Teknologi Informasi dan Komputasi - BATAN, "Image Reconstruction Algorithm for Elecrical Capacitance Tomography," BATAN, 2004.

[12] A. Yusuf, H. Sudibyo, D. Sudiana, A. S. Tamsir, I. Muttakin, W. Widada and W. P. Taruno, "Switch Configuration Effect on Stray Capacitance in Electrical Capacitance Volume Tomography Hardware," Telkomnika, vol. 14, no. 2, pp. 456-463, Juni 2016. 